\title{
New Spectrophotometric Estimation and Cloud Point Extraction of Cefdinir
}

\author{
Mohammed Jasim M. Hassan ${ }^{1^{*}}$ \\ Omar Qusay Mizher ${ }^{2}$
}

\author{
Received 7/5/2018, Accepted 26/9/2018, Published 9/12/2018
}

This work is licensed under a Creative Commons Attribution 4.0 International License.

\begin{abstract}
:
A sensitive spectrophotometric method was developed for the estimation of cefdinir (CFD), a cephalosporin species. This study involves two methods, and the first method includes the preparing of azo dye by the reaction of CFD diazonium salt with 4-Tert-Butylphenol (4-TBP) and 2-Naphthol (2-NPT) in alkaline medium, which shows colored dyes measured at $\lambda_{\max } 490$ and $535 \mathrm{~nm}$, respectively. Beer's law was obeyed along the concentration range of (3-100) $\mu \mathrm{g} \cdot \mathrm{ml}^{-1}$. The limits of detection were $0.246,0.447 \mu \mathrm{g} \cdot \mathrm{ml}^{-1}$ and molar absorptivities were $0.6129 \times 10^{4}, 0.3361 \times 10^{4} \mathrm{~L}_{\mathrm{mol}}{ }^{-1} \mathrm{~cm}^{-1}$ for $(\mathrm{CFD}-4-\mathrm{TBP})$ and (CFD-2-NPT), respectively. The second method includes preconcentration for cefdinir dyes by using cloud point extraction in the presence of Triton X-114 (10\% v/v) and recording measurements using the UV-Visible technique. Cloud point extraction enables the drug to be precisely estimated under the optimal experimental conditions. The concentrations were ranged between $(0.1-6.0)$ and $(0.2-6.0) \mu \mathrm{g} \cdot \mathrm{ml}^{-1}$. The limits of detection were 0.032 , $0.054 \mu \mathrm{g} . \mathrm{ml}^{-1}$ and molar absorptivities were $0.4733 \times 10^{5}, 0.2788 \times 10^{5} \mathrm{~L}_{\mathrm{mol}} \mathrm{m}^{-1} \mathrm{~cm}^{-1}$, respectively. Enrichment factors were 24.61, 24.58, and distribution coefficients were 1526, 1393 for (CFD-4-TBP), (CFD-2-NPT), respectively. The proposed methods have been applied for the determination of CFD in commercial formulation with no interference. The results appear to be no significant difference between the two methods.
\end{abstract}

Keywords: Cefdinir, Cloud point, Diazotization, Spectrophotometric, Triton X-114.

\section{Introduction:}

Chemically, cefdinir (CFD) is $[6 \mathrm{R}-[6 \alpha, 7 \beta$ (Z)]]-7- [[(2- amino-4- thiazolyl) (hydroxyimino) acetyl] amino]-3-ethenyl-8-oxo-5-thia-1- azabicyclo [4.2.0] oct-2-ene-2-carboxylic acid (Fig. 1). It is a broad-spectrum, semi-synthetic, and thirdgeneration cephalosporin (1). The molecular formula of CFD is $\mathrm{C}_{14} \mathrm{H}_{13} \mathrm{~N}_{5} \mathrm{O}_{5} \mathrm{~S}_{2}$, with a molecular weight of 395.42 (2). It has a broad spectrum of activity with excellent therapeutic action, specifically antimicrobial activity, against susceptible Gram-positive bacteria and Gramnegative bacteria. It also has excellent efficacy, convenient dosing and favourable tolerability compared with other antimicrobial agents. CFD was studied the United States Pharmacopoeia (USP) and Japanese Pharmacopoeia (JP) (3). Both USP and JP use a high-performance liquid chromatography (HPLC) method when assaying the raw material, capsules and oral powder for suspension.

1,2 Department of Chemistry, College of Science, University of Mustansiriyah, Baghdad, Iraq.

*Corresponding

dr.moh2004@uomustansiriyah.edu.iq

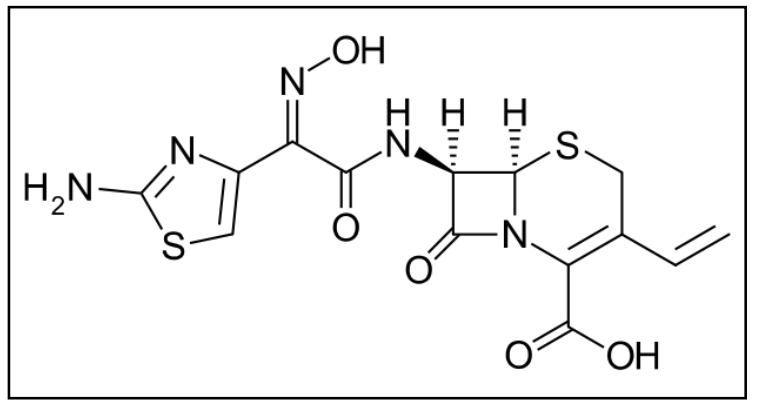

Figure 1. Structural formula for cefdinir

Many studies have been performed which estimate CFD in pharmaceutical preparations, involving HPLC (4), spectrofluorometric (5), spectrophotometry $(5,6)$, HPLC-MS/MS (2) and electrochemical methods (7). The extraction of Cloud point is a process of separation, preconcentration, fast, selective and sensitive method that has been widely applied to micro quantities of inorganic and organic species (8). CPE is an analytical method that has the ability to improve the detection limit and other analytical parameters, which studies the separation and pre-concentration of micro amounts of generally hydrophobic organic compounds and elements (9). Several papers were published using these methods to estimate active ingredients in industrial drugs $(10,11)$. Cloud point 
extraction has several advantages, such as inexpensive, high pre-concentration efficiency, reduced toxicity, simple procedure and green chemistry. Using these techniques, a hydrophobic analyte can be concentrated to a small volume of the surfactant-rich phase (12). The separated surfactant-rich phase can be directly subjected to HPLC or flow-injection analysis $(13,14)$. In this study, a new analytical method was developed for estimation of cefdinir, which is based on the diazotization-coupling reaction and cloud point extraction (CPE). In this article, the estimate and detection of trace concentration of CFD in the form of an azo dye and CPE-spectrophotometry. Statistical calculations show that this study could be applied to sample small batches of pharmaceutical drugs, including individual pills and bottles on the shelves of local pharmacies. This study is a new method for the estimation of cefdinir, where the diazotization-coupling and cloud point extraction methods are novel for this compound.

\section{Materials and Methods: Apparatus}

Spectral measurements were performed by ADVANCED MICROPROCESSOR UV-VIS SPECTROPHTOMETER SINGLE BEAM LI-295, Lasany ${ }^{\circledR}$ - (India), with a $1.0 \mathrm{~cm}$ quartz cell. An ultrasonic and thermostatic water bath, from Elma Hans Schmidbauer GmbH \&Co. KG, was used for the extraction of samples and the study temperature effects on cloud point extraction (CPE). A centrifuge (HERMLE LABORTECHNIK Z 200 A, Germany) was used to complete phase separation. An Electronic Balance Mettle Adventurer pro AV264 (Switzerland) and $\mathrm{pH}$ meter, type inoLab7110, WTW $^{\circledR}$ (Germany) were also used.

Reagents

All chemicals were of analytical grade and were purchased from Merck KGaA (Darmstadt, Germany). Cefdinir was obtained from the Quality Control Lab (The General Company for the Pharmaceutical Industry - Samarra).

\section{Preparations for the standard solutions \\ Preparations for the drug stock solution}

A Stock solution $\left(1000 \mu \mathrm{g} / \mathrm{ml}, 0.252 \times 10^{-2}\right.$ $\mathrm{M})$ of cefdinir was prepared by dissolving $0.1 \mathrm{~g}$ of the drug in $100 \mathrm{~mL}$ of double distilled water and $\mathrm{A}$ few drops of $1 \mathrm{M} \mathrm{NaOH}$ were added to ensure complete dissolution.

\section{Preparation for the sample solutions}

Capsules: Ten capsules containing cefdinir were carefully weighed from the commercial products (Sefarin ${ }^{\circledR}$ and Azord $\left.{ }^{\circledR}\right)$. Each capsule was weighted separately, and then the average weight of each capsule was extracted. The mean capsule weights were $0.35512 \mathrm{~g}, 0.36672 \mathrm{~g}$, respectively. An aliquot of the target drug was dissolved in double distilled water with few drops of $1 \mathrm{M} \mathrm{NaOH}$ and filled to a volume of $100 \mathrm{ml}$.

\section{Preparation of 4-Tert-Butylphenol (4-TBP) solution}

A $0.252 \times 10^{-2} \mathrm{M}$ solution of 4 -TBP was prepared by dissolving $0.0378 \mathrm{~g}$ of it in $100 \mathrm{ml}$ of double distilled water with a small amount of $1 \mathrm{M}$ $\mathrm{NaOH}$.

\section{Preparation of 2-Naphthol (2-NPT) solution}

A $0.252 \times 10^{-2} \mathrm{M}$ solution of 2 -NPT was prepared by dissolving $0.0363 \mathrm{~g}$ of it in $100 \mathrm{ml}$ of double distilled water with a small amount of $1 \mathrm{M}$ $\mathrm{NaOH}$.

\section{Other solutions}

A $50 \% \quad w / v \quad \mathrm{NaOH} \quad(12.5 \mathrm{M}), 1 \% \quad \mathrm{w} / \mathrm{v}$ $\mathrm{NaNO}_{2}(0.144 \mathrm{M}), 4 \%$ w/v urea, $10 \%$ v/v Triton X$114,0.01 \mathrm{M}(0.3644 \mathrm{~g}$ in $100 \mathrm{ml}$ of double distilled water) hexadecyltrimethylammonium bromide (CTAB), $5 \%$ w/ $/ \mathrm{Na}_{2} \mathrm{SO}_{4}$ solutions were prepared in double distilled water and $6.2 \mathrm{M} \mathrm{HCl}(1: 1$ ratio) were prepared for the following procedures.

\section{General procedure of Diazotization-coupling Reaction:}

A series of differing concentrations (3-100 $\mu \mathrm{g} / \mathrm{ml}$ ) were prepared from a standard solution of cefdinir, by adding different volumes of the stock solution $\left(1000 \mu \mathrm{g} / \mathrm{ml}, 0.252 \times 10^{-2} \mathrm{M}\right)$ in two series of volumetric flasks $(20 \mathrm{ml})$ which was This was placed in an ice bath for $2 \mathrm{~min}$. After that, $(1.75,1.5 \mathrm{~mL})$ of $6.2 \mathrm{M} \mathrm{HCl}$ and $(1,0.75 \mathrm{~mL})$ of $1 \%$ $\mathrm{NaNO}_{2}$ were added in two series of volumetric flasks. After $10 \mathrm{~min}, 2 \mathrm{~mL}$ of 4 -TBP and 2-NPT $\left(0.252 \times 10^{-2} \mathrm{M}\right)$ were added to the flasks respectively. Finally, $1.25 \mathrm{ml}$ of $\mathrm{NaOH}(50 \% \mathrm{w} / \mathrm{v})$ was added to both of the flasks with gentle mixing and the volume was completed with a distilled water. The absorbance of coloured products was measured at $\lambda_{\max }(490,535 \mathrm{~nm})$ for CFD-4-TBP, CFD-2-NPT, respectively against their reagent blank, which was prepared with the same steps.

\section{General procedure of CPE-spectrophotometry method}

Different concentrations, ranging from 0.1$6.0 \mu \mathrm{g} / \mathrm{ml}$ and $0.2-6.0 \mu \mathrm{g} / \mathrm{ml}$ from the two coloured dyes formed in the previous method (CFD-4-TBP and CFD-2-NPT, respectively) were transferred to a two series of $15 \mathrm{ml}$ centrifuge tubes. Using these tubes, $0.75,1.5 \mathrm{ml}$ of Triton X-114 (10\% v/v), $(2,1$ $\mathrm{ml}$ of $0.01 \mathrm{M})$ cationic surfactant $(\mathrm{CTAB})$ and $2.5 \mathrm{ml}$ of $(5 \% \mathrm{w} / \mathrm{v}) \mathrm{Na}_{2} \mathrm{SO}_{4}$ were added to that series. After that, the volume was completed up to $12.5 \mathrm{ml}$, and 
the tubes were put in an ultrasonic-thermostatic water bath device. The samples were placed under ultrasonic effect for 2 minutes to $\operatorname{mix}$ the components carefully at $70,60{ }^{\circ} \mathrm{C}$ for $75,45 \mathrm{~min}$ for CFD-4-TBP, CFD-2-NPT, respectively until the formation of a cloudy solution and separation of the mixture into two phases. Then the tubes were transferred to the centrifuge for $5 \mathrm{~min}$ at $4000-\mathrm{rpm}$ speed to complete the separation. The centrifuge tubes were placed in an ice bath until the micellar phase settles at the bottom of the tube and the aqueous phase was removed. At this point, $0.5 \mathrm{ml}$ of ethanol was added to dilute the micellar phase (dye) and measured at $\lambda_{\max } 505,545 \mathrm{~nm}$ for each of the CFD-4-TBP and CFD-2-NPT, respectively. There was a displacement of the maximum wavelength due to changing in the solvent type (ethanol). The capacity of cell used $1 \mathrm{ml}(\mathrm{L}: 1 \mathrm{~cm})$. A blank solution was prepared under the same conditions.

\section{Result and Discussion: \\ Part-I (the diazotization-coupling method) Absorption spectra}

Figures 2 and 3 show the spectral readout of a $100 \mu \mathrm{g} / \mathrm{ml}$ solution of CFD-4-TBP and CFD-2-NPT against their blank solutions recorded under the optimal conditions. The spectra show that the $\lambda_{\max }$ for the cited drug were $490 \mathrm{~nm}$ and $535 \mathrm{~nm}$ for CFD-4-TBP and CFD-2-NPT, respectively.

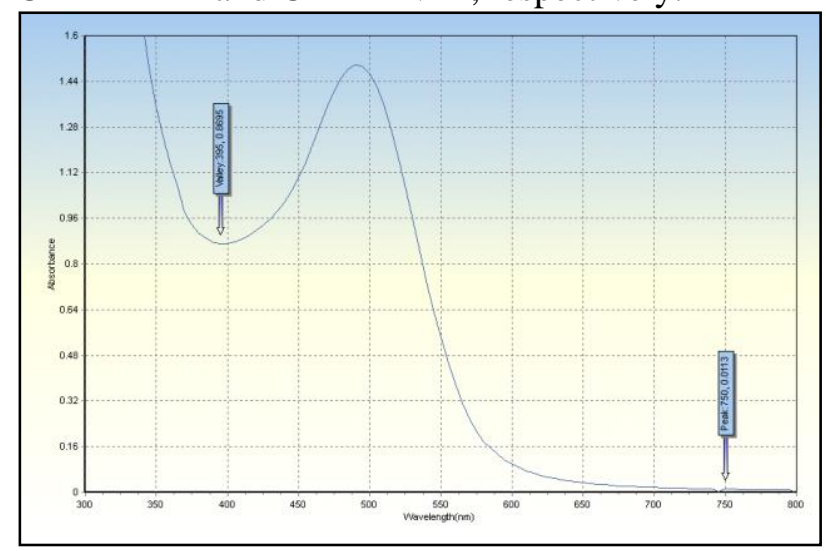

Figure 2. Absorption spectrum for $100 \mu \mathrm{g} / \mathrm{ml}$ of CFD-4-TBP against the reagent blank

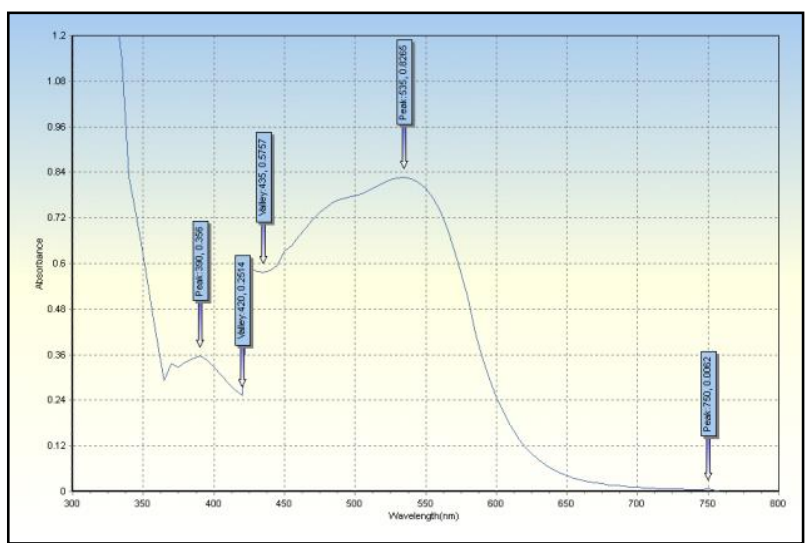

Figure 3. Absorption spectrum for $100 \mu \mathrm{g} / \mathrm{ml}$ of CFD-2-NPT against the reagent blank

\section{Optimization of experimental conditions}

Factors influencing diazotization-coupling reaction were studied to reach the maximum analytical signal. All these studies were performed with $100 \mu \mathrm{g} / \mathrm{ml}$ of cefdinir standard solution in 20 $\mathrm{ml}$ volumetric flasks.

The effect of the acid type on the diazotization-coupling was studied. Several acids have been used: $\mathrm{H}_{2} \mathrm{SO}_{4}, \mathrm{HCl}, \mathrm{HNO}_{3}$, and $\mathrm{CH}_{3} \mathrm{COOH}$ diluted $(1: 1)$. The obtained results indicate that $\mathrm{HCl}(1: 1)$ was the optimum acid used in this method because it gives the highest absorbance signal for both dyes, as it is shown in Table 1.

Table1 . Effect of acid type on absorbance signal of CFD $(100 \mu \mathrm{g} / \mathrm{ml})$

\begin{tabular}{ccc}
\hline $\begin{array}{c}\text { Type of acid } \\
(\mathbf{1 : 1})\end{array}$ & $\begin{array}{c}\text { Abs of CFD-4- } \\
\text { TBP at 490nm }\end{array}$ & $\begin{array}{c}\text { Abs of CFD-2- } \\
\text { NPT at 535nm }\end{array}$ \\
\hline $\mathrm{HCl}$ & 1.260 & $\mathbf{0 . 5 8 3}$ \\
$\mathrm{H}_{2} \mathrm{SO}_{4}$ & 0.703 & $\mathbf{0 . 5 3 1}$ \\
$\mathrm{HNO}_{3}$ & 1.255 & $\mathbf{0 . 5 4 5}$ \\
$\mathrm{CH}_{3} \mathrm{COOH}$ & 0.571 & $\mathbf{0 . 2 2 0}$ \\
\hline
\end{tabular}

The effect of $(1: 1) \mathrm{HCl}$ volume on the diazotization-coupling reaction was studied. Different volumes (0.25-2.00 ml) of (1:1) $\mathrm{HCl}$ were used to obtain the optimum absorbance signal. The optimum volume of acid for the determination of CFD-4-TBP and CFD-2-NPT was $1.75 \mathrm{ml}$ (0.543 $\mathrm{M})$ and $1.5 \mathrm{ml}(0.465 \mathrm{M})$ respectively, in a final volume of $20 \mathrm{ml}$, as it is shown in Figure 4. 


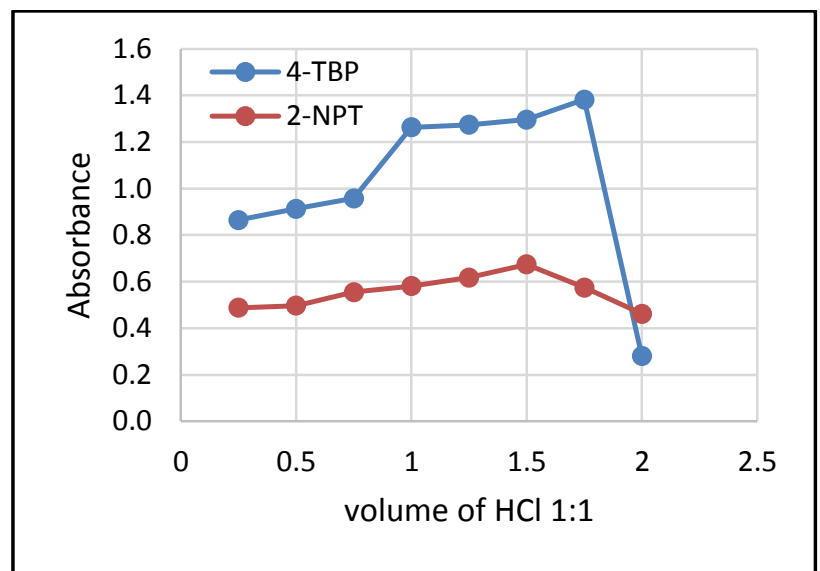

Figure 4. Effect of (6.2M) HCl volume

The effect of the volume of $1 \% \mathrm{NaNO}_{2}$ on the diazotization reaction was studied. The amount of sodium nitrite has a significant role in this reaction as the use of the appropriate concentration that leads to the rapidity and completeness of the reaction (10). Different volumes ranging from 0.25 $2.00 \mathrm{~mL}$ of $1 \% \mathrm{NaNO} 2$ were used, and the optimum volumes of the $\mathrm{NaNO}_{2}$ solution for CFD-4-TBP and CFD-2 -NPT were 1.00, $0.75 \mathrm{ml}$ respectively, as it is shown in Figure 5.

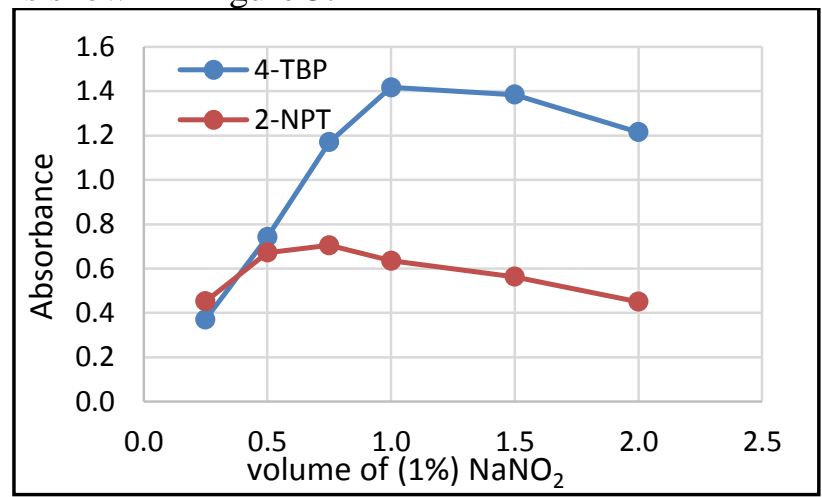

Figure 5. Effect of $1 \%$ sodium nitrite volume

The reaction time after the addition of sodium nitrite has an important effect on the value of absorbance signal because the diazonium salts are generally unstable (15). Several intervals after the addition of nitrite (5-30 $\mathrm{min})$ were tried and the optimum reaction time for CFD-4-TBP and CFD-2NPT was found at 10 minutes, as it gave the highest absorbance signal for both dyes.

The residual nitrite, in the form of nitrous acid, is undesirable as it leads to side reactions. Therefore, it must be eliminated by the addition of urea solution $4 \% \mathrm{w} / \mathrm{v}$, according to the reaction equation below (16):

$$
\mathrm{H}_{2} \mathrm{NCONH}_{2}+\mathrm{HNO}_{2} \rightarrow \mathrm{CO}_{2} \uparrow+2 \mathrm{~N}_{2} \uparrow+3 \mathrm{H}_{2} \mathrm{O}
$$

However, through testing different volumes of urea $4 \%(0-4 \mathrm{ml})$, we have determined that there is no need for the addition of this solution since diazotization reaction was without urea, which lead to the highest intensity of absorption in both dyes.

The effect of $\mathrm{NaOH}, \mathrm{KOH}$ and $\mathrm{NH}_{3}$ were studied. The highest absorbance signal of both dyes was obtained when using (50\%) $\mathrm{NaOH}$. Different volumes, ranging from $0.25-2.00 \mathrm{ml}$ of $50 \% \mathrm{NaOH}$ were studied to obtain the highest absorbance signal. The optimum absorbance signal of the two dyes was attained with $1.25 \mathrm{ml}$, as it is shown in Figure 6.

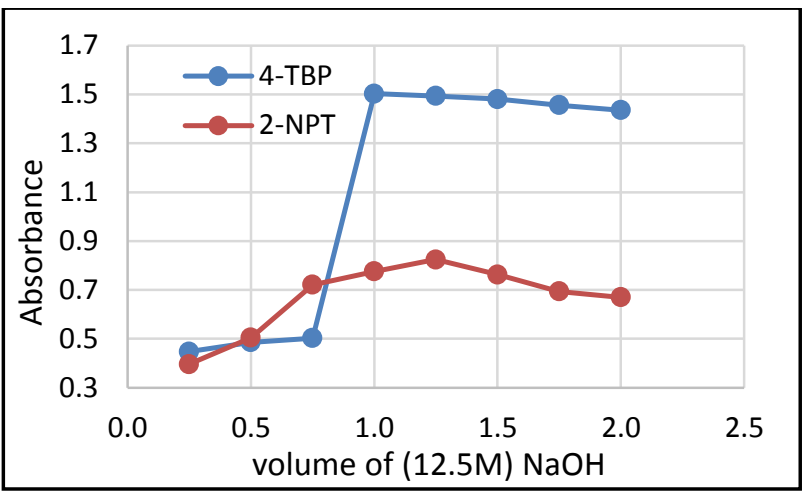

Figure 6. Effect of (12.5M) $\mathrm{NaOH}$ volume

\section{Effects of the sequence of additions}

The sequence of the additions of reagents was studied with its effect on the absorption intensity of the formed dyes. The results show that the sequence of (diazonium salt + reagent + base) is optimal since it gives the highest absorbance signal in both cases, as it is shown in Table 2.

Table 2.Effect of additions sequence on absorbance signal

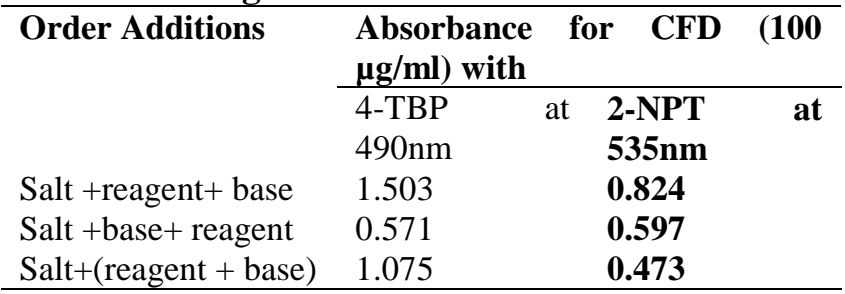

The Effect of reagent volume and the nature of colored dye product

Different volumes, ranging from $0.25-3.00 \mathrm{ml}$, of the $0.252 \times 10^{-2} \mathrm{M}$ reagents 4 -TBP and 2-NPT were studied with $2 \mathrm{ml}$ of $0.252 \times 10^{-2} \mathrm{M}$ for cefdinir solution. The optimum volume of the reagents in both cases was $2.00 \mathrm{ml}$. After that, the absorbance volume signal was almost constant. The results were used to determine the ratio of drug: reagent according to mole ratio method. The results indicate that the dyes have a combination of 1:1 ratio of diazotized CFD to both reagents, as it is shown in Figure 7. 


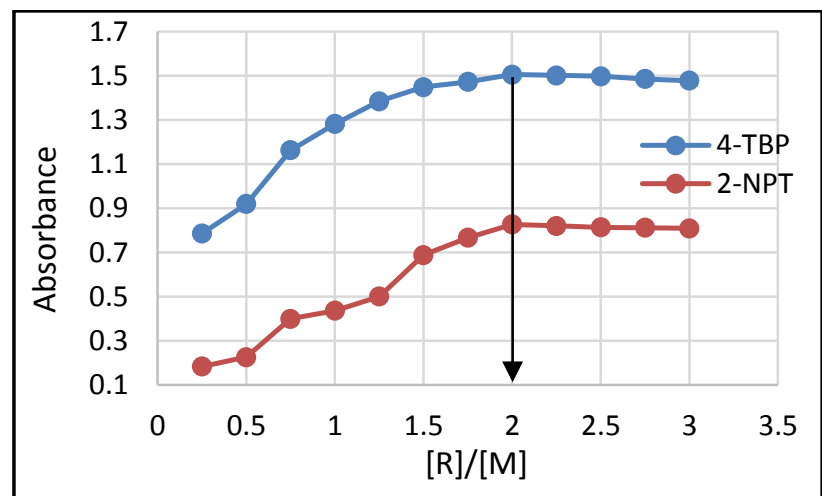

Figure 7. The mole-ratio plot for diazotized cefdinir to 4-TBP and 2-NPT

The possible reaction mechanism can be written as in the Figure 8:

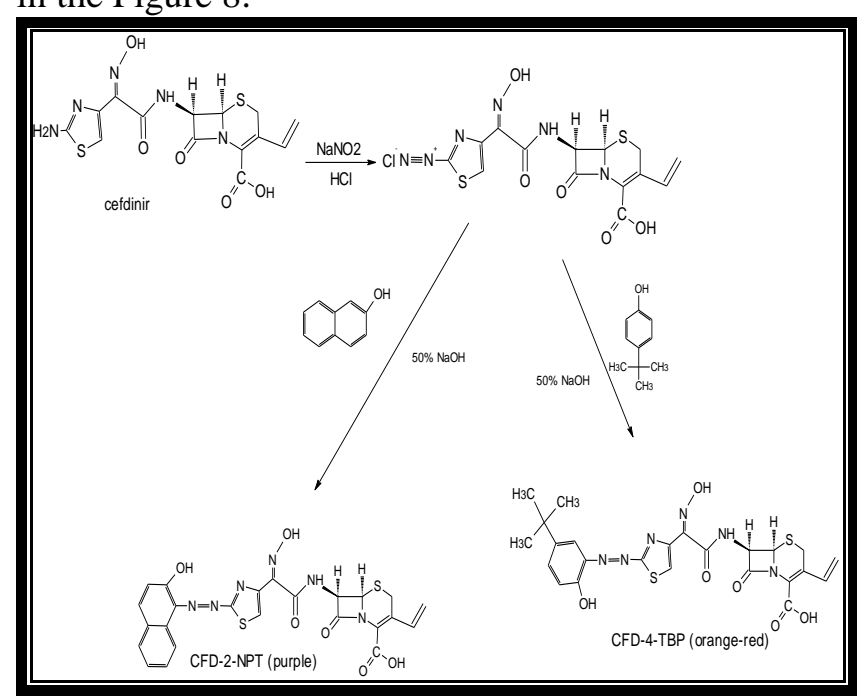

Figure 8. The suggested mechanism for the diazotization-coupling reaction

Calibration curves and analytical data

Under the optimal experimental conditions, the calibration curves were constructed. The optical characteristics such as Beer's law limits, molar absorptivity, Sandell's sensitivity, LOD and LOQ in each methods were calculated. In addition, the regression characteristics slope (b), intercept (a), and correlation coefficient $(r)$ were derived using Microsoft Excel Data Analysis were calculated and are presented in Table 3, and Figure 9 shows the calibration curves. Specifically, excellent linearity within the range of concentrations utilized. The limit of detection (LOD) was calculated based on $L O D=3 \times\left(S_{B} / b\right)$ and limits of quantification (LOQ) based on $L O Q=10 \times\left(S_{B} / b\right)$, where $S_{B}$ and $b$ are the standard deviation of 10 blank signals, and slope or sensitivity of the calibration curves, respectively (17).

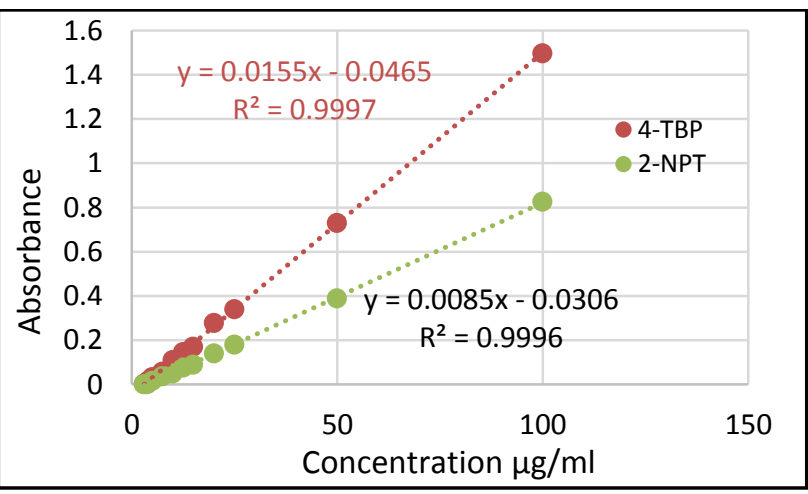

Figure 9. Calibration curves of CFD-4-TBP \& CFD-2-NPT

Table 3. Characteristic parameters of the proposed diazotization-coupling methods

\begin{tabular}{|c|c|c|}
\hline Parameter & CFD-4-TBP & CFD-2-NPT \\
\hline Color of product & Orange-red & purple \\
\hline$\lambda_{\max }(\mathbf{n m})$ & 490 & 535 \\
\hline $\begin{array}{l}\text { Dynamic range } \\
\left(\mu \mathrm{g} \cdot \mathrm{ml}^{-1}\right)\end{array}$ & $(3-100)$ & $(3-100)$ \\
\hline $\begin{array}{l}\text { Molar } \\
\text { absorptivity, } \mathcal{E} \\
\left(\text { L.mol }{ }^{-1} \cdot \mathrm{cm}^{-1}\right)\end{array}$ & $0.6129 \times 10^{4}$ & $0.3361 \times 10^{4}$ \\
\hline $\begin{array}{l}\text { Regression } \\
\text { equation }\end{array}$ & $\begin{array}{l}y=0.0155 x- \\
0.0465\end{array}$ & $\begin{array}{l}y=0.0085 x- \\
0.0306\end{array}$ \\
\hline $\begin{array}{l}\text { Sandell sensitivity, } \\
\text { S ( } \mu \text { g .cm } \\
\left.{ }^{-}\right) / 0.001 \mathrm{~A} . \mathrm{U}\end{array}$ & 0.0645 & 0.1176 \\
\hline Intercept (a) & -0.0465 & -0.0306 \\
\hline $\begin{array}{l}\text { Slope (b) (L.mg- } \\
\left.{ }^{1} \mathrm{~cm}^{-1}\right)\end{array}$ & 0.0155 & 0.0085 \\
\hline $\begin{array}{l}\text { Coefficient of } \\
\text { determination } \% \\
\mathbf{R}^{2}\end{array}$ & 99.97 & 99.96 \\
\hline $\begin{array}{l}\text { Correlation } \\
\text { coefficient (r) }\end{array}$ & 0.9998 & 0.9998 \\
\hline $\begin{array}{l}\text { Limit of detection } \\
\left(\mu \mathrm{g} \cdot \mathrm{mL}^{-1}\right)\end{array}$ & 0.246 & 0.447 \\
\hline $\begin{array}{l}\text { Limit of } \\
\text { quantification } \\
\left(\mu \mathrm{g} \cdot \mathrm{mL}^{-1}\right)\end{array}$ & 0.820 & 1.489 \\
\hline 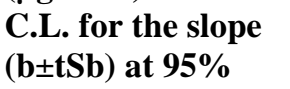 & $0.0155 \pm 0.0003$ & $0.0085 \pm 0.0001$ \\
\hline $\begin{array}{l}\text { C.L. for the } \\
\text { intercept }(\mathrm{a} \pm \mathrm{tSa}) \\
\text { at } 95 \%\end{array}$ & $-0.0465 \pm 0.0101$ & $-0.0306 \pm 0.0050$ \\
\hline $\begin{array}{l}\text { Standard error } \\
\text { for regression line } \\
\left(\mathrm{S}_{\mathrm{y} / \mathrm{x}}\right)\end{array}$ & 0.0096 & 0.0053 \\
\hline
\end{tabular}




\section{Effect of Interferences}

The effect of some foreign excipients on the determination of pure drug was studied, which are often added to the commercial pharmaceutical. 500 $\mu \mathrm{g} / \mathrm{ml}$ of these compounds were added individually to $100 \mu \mathrm{g} / \mathrm{ml}$ of pure drug before determination.

Table 4. Effect of foreign compounds on pure drug

\begin{tabular}{ccc}
\hline \multirow{2}{*}{$\begin{array}{c}\text { Foreign } \\
\text { Compound }\end{array}$} & $\begin{array}{c}\text { \% Recovery of 100 } \boldsymbol{\mu g} / \mathbf{m l} \\
\text { CFD per } \mathbf{5 0 0} \boldsymbol{\mu g} / \mathbf{m l} \text { Foreign } \\
\text { compound added }\end{array}$ \\
\cline { 2 - 3 } Sucrose & CFD-TBP & CFD-2-NPT \\
Fructose & 99.34 & 99.68 \\
Lactose & 99.38 & 99.67 \\
Maltose & 99.40 & 99.66 \\
Sodium benzoate & 99.34 & 99.49 \\
Starch & 99.32 & 99.50 \\
\hline
\end{tabular}

The results in Table 4 show that the presence of these compounds has no significant effect on the determination of $100 \mu \mathrm{g} / \mathrm{ml}$ of the cited drug since the recovery percentage was ranged from 99.29-99.40 and from 99.37-99.68 for both methods, respectively.

\section{Accuracy and Precision}

The accuracy and precision of the proposed methods were tested by analyzing five replicates of pure samples and commercial pharmaceuticals for three different concentrations from calibration curve. The values of the T-test and F-test were calculated and compared with the reported method (18) and shown in Tables 5 and 6. These results show that the suggested methods gave acceptable results in the estimation of the CFD with the comparison of the reported method (18). The excipients present in the pharmaceutical dosage forms are not interfered in the valuation, when it is analyzed by these methods, so it can be adopted in the estimation of the CFD.

Table 5. Accuracy and precision of the proposed methods for the estimation of pure samples and their comparison with the reported method

\begin{tabular}{|c|c|c|c|c|c|c|}
\hline \multirow{2}{*}{ Type Of Reagent } & \multicolumn{2}{|c|}{ amount of CFD $(\mu \mathrm{g} / \mathrm{ml})$} & \multirow{2}{*}{$\mathrm{E}_{\mathrm{rel}} \%$} & \multirow{2}{*}{ t-value } & \multirow{2}{*}{ F-value } & \multirow{2}{*}{ RSD\% (n=5) } \\
\hline & Taken & Found $^{*}$ & & & & \\
\hline \multirow{3}{*}{ 4-ТВP } & 10 & $10.03 \pm 0.14$ & 0.32 & & & 1.44 \\
\hline & 25 & $24.96 \pm 0.22$ & -0.15 & 1.53 & 12.06 & 0.87 \\
\hline & 50 & $50.10 \pm 0.10$ & 0.19 & & & 0.20 \\
\hline \multirow{3}{*}{ 2-NPT } & 10 & $10.14 \pm 0.18$ & 1.41 & & & 1.76 \\
\hline & 25 & $25.13 \pm 0.26$ & 0.52 & 0.53 & 1.03 & 1.05 \\
\hline & 50 & $49.84 \pm 0.30$ & -0.33 & & & 0.60 \\
\hline
\end{tabular}

Table 6. accuracy and precision of the methods proposed in the estimation of commercial pharmaceuticals

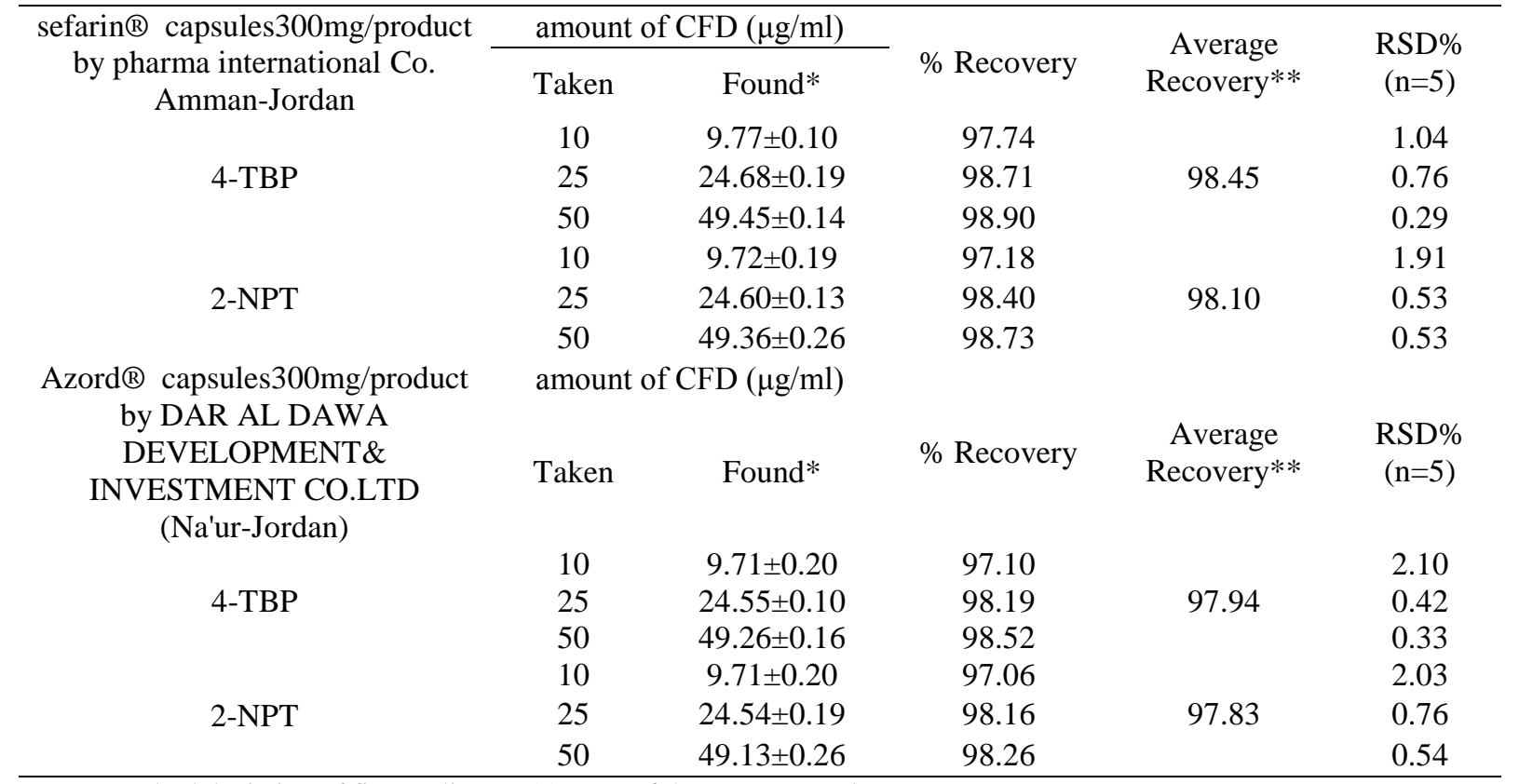

* Mean \pm standard deviation of five replicates. $* *$ Mean of three concentrations.

Theoretical values at $95 \%$ confidence limits, $\mathrm{t}=2.78, \mathrm{~F}=19$. 


\section{Part-II (the CPE-spectrophotometry method) Optimization of CPE to estimate CFD}

The optimal conditions of the separation and extraction method help to obtain the accurate concentration of the drug in the micellar phase and the highest absorption signal. These conditions are the amount of Triton X-114, the amount of cationic surfactant (CTAB), salt type and amount of salt, temperature, equilibration time and $\mathrm{pH}$ effect. The concentration of CFD in this study is $4 \mu \mathrm{g} / \mathrm{ml}$, and the $\mathrm{pH}$ value in the preliminary study is 12 .

The preconcentration factor theoretically depends on the surfactant concentration (19). The effect of $10 \% \mathrm{v} / \mathrm{v}$ Triton X-114 was studied by using different volumes ranging from $0.25-2.00 \mathrm{ml}$. The optimum efficiency of extraction was achieved at $(0.75,1.50 \mathrm{ml})$ for CFD-4-TBP and CFD-2-NPT, respectively as it is shown in Figure 10.

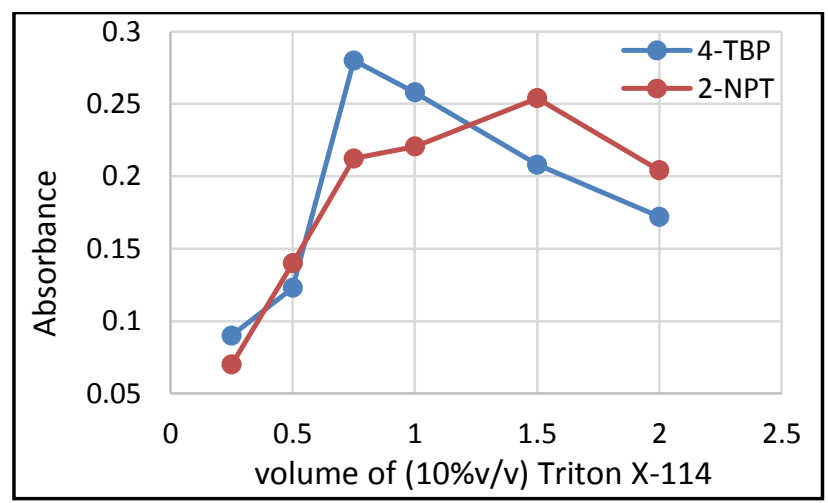

Figure 10. Effect of $(10 \%$ v/v) Triton X-114 volume

Mixed micelle formation depends on the nonionic and cationic surfactant concentrations and on the balance between these factors (17). The addition of CTAB increases the cloud point temperature because of the increase of the hydrophilic characteristic of the micellar phase. This can be explained recalling that the ionic surfactant molecules added are combined into nonionic micelles, changing the surface charge and increasing the repulsion among micelles, which makes them more hydrophilic (20). The effect of the volume of $(0.01 \mathrm{M}) \mathrm{CTAB}$ on the extraction efficiency was studied by using different volumes $(0-3 \mathrm{ml})$. The optimum volume was $(2,1 \mathrm{ml})$ for CFD-4-TBP and CFD-2-NPT, respectively. This is because it increases the efficiency of extraction and the concentration of the surfactant-rich phase and increases the pre-concentration factor, which results in an increase in the absorbance signal as it is shown in Figure 11.

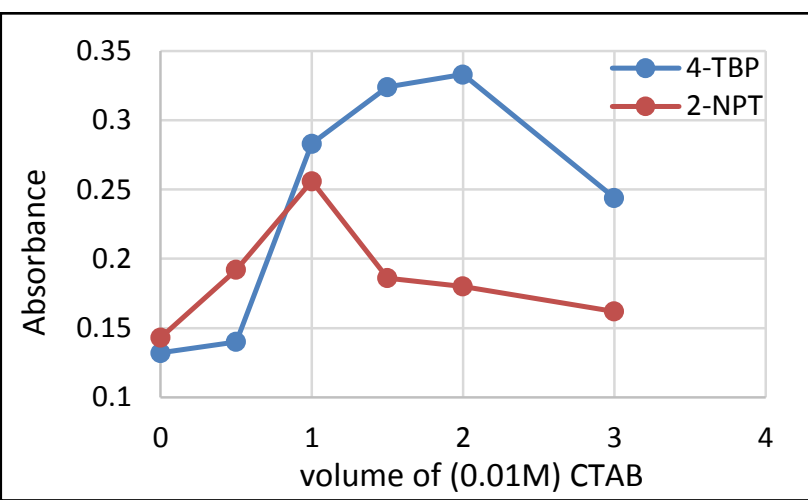

Figure 11. Effect of cationic surfactant CTAB volume

It was reported that the cloud point (CP) of mixed nonionic and ionic surfactants were reduced with the addition of a small quantity of inorganic salts (21). The CP depended on the nature and concentration of the salt added and the concentration of the surfactant used (22). The salting-in and salting-out effects could be used to interpret the electrolyte effects on the cloud points of a non-ionic surfactant (23). Various salts (sodium chloride, potassium chloride, sodium sulphate, sodium acetate) were studied by using $5 \% \mathrm{w} / \mathrm{v}$ solution to obtain the optimum extraction efficiency. In this study, $2.5 \mathrm{ml}$ of the $\mathrm{Na}_{2} \mathrm{SO}_{4}$ solution was found to give the results and to increase pre-concentration for both dyes.

It is most desirable to employ the lowest possible equilibration temperature and shortest equilibration time as a compromise between completion of extraction and the efficiency of phase separation (24). In the present work, the thermostatic water bath was kept in the range of 40$80{ }^{\circ} \mathrm{C}$ and the equilibration time was studied for a time span of 30-90 min to examine its dependence upon the extraction efficiency of the proposed method. The absorbance of the surfactant-rich phase reached a maximum value above $70,60{ }^{\circ} \mathrm{C}$ at 75,45 min for CFD-4-TBP and CFD-2-NPT, respectively.

Organic dyes can be affected by $\mathrm{pH}$, since they change color in different $\mathrm{pHs}$. Therefore, $\mathrm{pH}$ plays an important role in the extraction of them (25). The effect of the $\mathrm{pH}$ on both dyes extraction was assessed by varying the $\mathrm{pH}$ from 4 to 14 . The results indicates that optimal extraction efficiency is verified in the $\mathrm{pH}=12$.

\section{Calibration Curves and Analytical Data}

The measured absorbance at $505 \mathrm{~nm}$ and $545 \mathrm{~nm}$ versus different standard concentrations of CEF-4-TBP and CFD-2-NPT respectively, were plotted to construct calibration curves. The calibration curves were obtained by preconcentration of $12.5 \mathrm{ml}$ of both dyes in presence of $10 \% \mathrm{v} / \mathrm{v}$ Triton X-114 at $\mathrm{pH} 12$ under 
the optimum conditions, as it is shown in Figure 12. The analytical figures of merit of the suggested CPE-spectrophotometry method was evaluated with the recommended procedure under the optimum conditions for the target analyte are shown in Table 7.

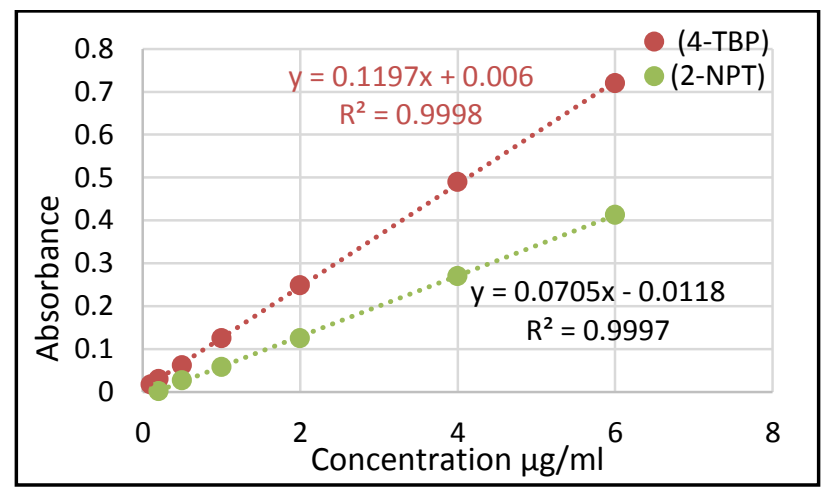

Figure 12. The calibration curve of the CPE method.

Table 7. Characteristic parameters for the regression equation of the proposed CPE method

\begin{tabular}{|c|c|c|}
\hline Parameters & CFD-4-TBP & CFD-2-NPT \\
\hline Color of product & purple & Purple \\
\hline$\lambda_{\max }(\mathrm{nm})$ & 505 & 545 \\
\hline Dynamic range $\left(\mu \mathrm{g} \cdot \mathrm{ml}^{-1}\right)$ & $(0.1-6.0)$ & $(0.2-6.0)$ \\
\hline Molar absorptivity, $\mathcal{E}\left(\mathrm{L} \cdot \mathrm{mol}^{-1} \cdot \mathrm{cm}^{-1}\right)$ & $0.4733 \times 10^{5}$ & $0.2788 \times 10^{5}$ \\
\hline Regression equation & $y=0.1197 x+0.006$ & $y=0.0705 x-0.0118$ \\
\hline Sandell sensitivity, $\mathrm{S}\left(\mu \mathrm{g} . \mathrm{cm}^{-2}\right) / 0.001 \mathrm{~A} . \mathrm{U}$ & 0.0084 & 0.0142 \\
\hline Intercept (a) & 0.006 & -0.0118 \\
\hline Slope (b) & 0.1197 & 0.0705 \\
\hline Coefficient of determination $\% \mathrm{R}^{2}$ & 99.98 & 99.97 \\
\hline Correlation coefficient $(\mathrm{r})$ & 0.9999 & 0.9999 \\
\hline Limit of detection $\left(\mu \mathrm{g} \cdot \mathrm{mL}^{-1}\right)$ & 0.032 & 0.054 \\
\hline Limit of quantification $\left(\mu \mathrm{g} \cdot \mathrm{mL}^{-1}\right)$ & 0.106 & 0.180 \\
\hline C.L. for the slope $(b \pm t S b)$ at $95 \%$ & $0.1197 \pm 0.0018$ & $0.0705 \pm 0.0017$ \\
\hline C.L. for the intercept $(a \pm t S a)$ at $95 \%$ & $0.006 \pm 0.0051$ & $-0.0118 \pm 0.0052$ \\
\hline Standard error for regression line $\left(\mathrm{S}_{\mathrm{y} / \mathrm{x}}\right)$ & 0.0038 & 0.0031 \\
\hline Enrichment (EF) factor & 24.61 & 24.58 \\
\hline Preconcentration factor $(\mathrm{PF})$ & 25 & 25 \\
\hline Distribution coefficient (D) & 1526 & 1393 \\
\hline
\end{tabular}

LOD and LOQ are determined from the slope (b) of calibration curves and the standard deviation of 10 blank signals $\left(\mathrm{S}_{\mathrm{B}}\right)$ as $\mathrm{LOD}=3 \times\left(\mathrm{S}_{\mathrm{B}}\right.$ $/ \mathrm{b})$ and $\mathrm{LOQ}=10 \times\left(\mathrm{S}_{\mathrm{B}} / \mathrm{b}\right)(17)$. The distribution coefficient is calculated as $\mathrm{D}=[\mathrm{M}]_{S} /[\mathrm{M}]_{\mathrm{W}}$, where $[\mathrm{M}]_{\mathrm{S}}$ and $[\mathrm{M}]_{\mathrm{W}}$, which are the final analyte concentrations in the surfactant-rich phase (SRP) and in the aqueous phase, respectively (26). The enrichment factor $(\mathrm{EF})$ is calculated as $\mathrm{EF}=\mathrm{C}_{S} / \mathrm{C}_{\mathrm{O}}$, where $\mathrm{C}_{S}$ and $\mathrm{C}_{O}$ are the analyte concentration in $\mathrm{SRP}$ and the analyte concentration in initial aqueous solution, respectively. The preconcentration factor is calculated as the ratio of a volume of the initial solution $\left(\mathrm{V}_{\mathrm{O}}\right)$ to that of the final solution $\left(\mathrm{V}_{\mathrm{S}}\right)$ after the preconcentration $\left(\mathrm{PF}=\mathrm{V}_{\mathrm{O}} / \mathrm{V}_{\mathrm{S}}\right)(27)$.

\section{Accuracy and Precision}

The accuracy and precision of the proposed methods were tested by analyzing five replicates of pure samples and commercial pharmaceuticals for three different concentrations. The value of the Ttest and F-test was calculated by comparing it to the reported method (18), as shown in the Tables 8 and 9. The statistical results show that the method is accepted in the estimation of the CFD compared to the reported method (18), so it can be adopted in the estimation of the CFD. 
Table 8. The accuracy and precision of the methods proposed in the estimation of pure samples and their comparison with the reported method

\begin{tabular}{|c|c|c|c|c|c|c|}
\hline \multirow{2}{*}{$\begin{array}{l}\text { Type Of } \\
\text { Reagent }\end{array}$} & \multicolumn{2}{|c|}{ amount of CFD $(\mu \mathrm{g} / \mathrm{ml})$} & \multirow{2}{*}{$\mathbf{E}_{\text {rel }} \%$} & \multirow{2}{*}{ t-value } & \multirow{2}{*}{ F-value } & \multirow{2}{*}{ RSD\% (n=5) } \\
\hline & Taken & Found ${ }^{*}$ & & & & \\
\hline & 2 & $1.99 \pm 0.02$ & -0.42 & & & 1.21 \\
\hline \multirow[t]{3}{*}{ 4-TBP } & 4 & $4.04 \pm 0.01$ & 0.88 & 1.02 & 1.73 & 0.33 \\
\hline & 6 & $6.02 \pm 0.04$ & 0.36 & & & 0.69 \\
\hline & 2 & $1.997 \pm 0.03$ & -0.14 & & & 1.59 \\
\hline \multirow[t]{2}{*}{ 2-NPT } & 4 & $4.03 \pm 0.02$ & 0.64 & 0.75 & 2.51 & 0.56 \\
\hline & 6 & $6.05 \pm 0.04$ & 0.90 & & & 0.60 \\
\hline
\end{tabular}

Table 9. Accuracy and precision of the methods proposed in the estimation of commercial pharmaceuticals

\begin{tabular}{|c|c|c|c|c|c|}
\hline \multirow{2}{*}{$\begin{array}{l}\text { sefarin }{ }^{\circledR} \\
\text { capsules300mg/product by } \\
\text { pharma international Co. } \\
\text { Amman-Jordan }\end{array}$} & \multicolumn{2}{|c|}{ amount of CFD $(\mu \mathrm{g} / \mathrm{ml})$} & \multirow{2}{*}{$\begin{array}{l}\text { \% } \\
\text { Recovery }\end{array}$} & \multirow{2}{*}{$\begin{array}{l}\text { Average } \\
\text { Recovery** }\end{array}$} & \multirow{2}{*}{$\begin{array}{l}\text { RSD\% } \\
(\mathbf{n}=5)\end{array}$} \\
\hline & Taken & Found* & & & \\
\hline \multirow[t]{3}{*}{$4-\mathrm{TBP}$} & 2 & $1.95 \pm 0.03$ & 97.74 & 98.41 & 1.51 \\
\hline & 4 & $3.96 \pm 0.02$ & 98.91 & & 0.63 \\
\hline & 6 & $5.91 \pm 0.01$ & 98.58 & & 0.22 \\
\hline \multirow[t]{3}{*}{ 2-NPT } & 2 & $1.940 \pm 0.04$ & 97.02 & 98.27 & 1.86 \\
\hline & 4 & $3.95 \pm 0.04$ & 98.87 & & 0.91 \\
\hline & 6 & $5.93 \pm 0.03$ & 98.91 & & 0.52 \\
\hline Azord® & \multicolumn{2}{|c|}{ amount of $\mathrm{CFD}(\mu \mathrm{g} / \mathrm{ml})$} & $\%$ Recovery & Average & $\mathrm{RSD} \%$ \\
\hline capsules $300 \mathrm{mg} /$ product by & Taken & Found* & & Recovery** & $(\mathrm{n}=5)$ \\
\hline DAR AL DAWA & & & & & \\
\hline \multicolumn{6}{|l|}{ 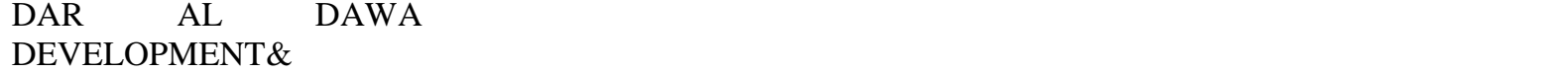 } \\
\hline \multicolumn{6}{|l|}{$\begin{array}{l}\text { INVESTMENT } \\
\text { (Na'ur-Jordan) }\end{array}$} \\
\hline \multirow[t]{3}{*}{$4-\mathrm{TBP}$} & 2 & $1.95 \pm 0.02$ & 97.33 & 98.07 & 0.96 \\
\hline & 4 & $3.94 \pm 0.01$ & 98.58 & & 0.33 \\
\hline & 6 & $5.90 \pm 0.03$ & 98.30 & & 0.45 \\
\hline \multirow[t]{3}{*}{ 2-NPT } & 2 & $1.95 \pm 0.02$ & 97.73 & 98.06 & 1.15 \\
\hline & 4 & $3.93 \pm 0.04$ & 98.16 & & 0.92 \\
\hline & 6 & $5.90 \pm 0.02$ & 98.30 & & 0.38 \\
\hline
\end{tabular}

* Mean \pm standard deviation of five replicates. **Mean of three concentrations.

Theoretical values at $95 \%$ confidence limits, $\mathrm{t}=2.78, \mathrm{~F}=19$.

\section{Comparison of the methods}

Table 10, shows the comparison between the suggested methods and that of another literature spectrophotometric methods of some measured analytical parameters. The results show that the methods have reasonable accuracy compared with the other methods.

Table 10. Some suggested methods for estimating cefdinir by spectrophotometry

\begin{tabular}{|c|c|c|c|c|c|}
\hline Coupling Reagent Used/ Reaction Type & $\begin{array}{l}\lambda_{\max } \\
(\mathrm{nm})\end{array}$ & Linearity $\mu \mathrm{g} / \mathrm{ml}$ & $\mathrm{LOD} \mu \mathrm{g} / \mathrm{ml}$ & $\varepsilon\left(1 \mathrm{~mol}^{-1} \mathrm{~cm}^{-1}\right)$ & Ref \\
\hline Catechol-IO4/ oxidative coupling & 460 & $50-250$ & - & $4.5 \times 10^{3}$ & (28) \\
\hline MBTH-FeCl3/ oxidative coupling & 660 & $0.5-6.0$ & 0.04 & $6.20 \times 10^{4}$ & (3) \\
\hline 1,10-PTL-FeCl3/ oxidation & 512 & $2-8$ & 0.5176 & $0.2991 \times 10^{4}$ & (29) \\
\hline acac- $\mathrm{CH}_{2} \mathrm{O} /$ condensation & 403 & $10-100$ & 1.2734 & 2523.41 & $(5)$ \\
\hline $\mathrm{K} 3 \mathrm{Fe}(\mathrm{CN}) 6-\mathrm{FeCl} 3 /$ Charge transfer & 700 & 4-12 & 0.5176 & $1.423 \times 10^{3}$ & (29) \\
\hline NBD-Cl/ hydrolysis & 390 & $5-30$ & 0.280 & $0.618 \times 10^{4}$ & (30) \\
\hline $\mathrm{Fe}(\mathrm{NH} 4)_{2}(\mathrm{SO} 4)_{2} /$ complexation & 550 & $8-160$ & 0.56 & 3720 & (31) \\
\hline 4-tert-butylphenol/ diazotization & 490 & $3-100$ & 0.246 & $0.6129 \times 10^{4}$ & \multirow{4}{*}{ Present study } \\
\hline 4-tert-butylphenol/ CPE & 505 & $0.1-6.0$ & 0.032 & $0.4733 \times 10^{5}$ & \\
\hline 2-Naphthol/ diazotization & 535 & $3-100$ & 0.447 & $0.3361 \times 10^{4}$ & \\
\hline 2-Naphthol/ CPE & 545 & $0.2-6.0$ & 0.054 & $0.2788 \times 10^{5}$ & \\
\hline
\end{tabular}




\section{Conclusion:}

The research includes two simple, sensitive, fast and inexpensive methods for estimating cefdinir, as the 4-TBP and 2-NPT reagents are available and cheap. The first method (diazotization-coupling) involves the conversion of the cefdinir into a colored dye measured by a UVVis spectrophotometer. The second method involves the pre-concentration of colored dye by the cloud-point extraction method to obtain the maximum possible analytical information and to eliminate the interferences that may exist during the measurement. This method is the first method to extract the CFD at the cloud point. These methods have been successfully applied in the estimation of cefdinir in pharmaceuticals.

\section{Conflicts of Interest: None.}

\section{References:}

1. Al-Badr AA, Alasseiri FA. Cefdinir. Profiles Drug Subst Excipients Relat Methodol [Internet]. 2014 Jan 1 [cited 2018 Sep 12];39:41-112.

2. Tutunji LF, Bayyari M Al, Shilbayeh S, Tutunji MF. Determination of Cefdinir in Human Plasma using HPLC Coupled with Tandem Mass Spectroscopy: Application to Bioequivalence Studies. Jordan J Pharm Sci. 2015;8(2):123-39.

3. Abou-Taleb NH, El-Wasseef DR, El-Sherbiny DT, El-Ashry SM. Optimizing the spectrofluorimetric determination of cefdinir through a Taguchi experimental design approach. Luminescence. 2016 May;31(3):856-64.

4. A Akl M, A Ahmed M. Development and Validation of a Liquid Chromatographic Method for the Determination of Cefdinir Residues on Manufacturing Equipment Surfaces. J Chromatogr Sep Tech J Chromatogr Sep Tech. 2013;04(03):1-4.

5. Ibrahim F, Wahba MEK, Magdy G. Analytical method development and validation of spectrofluorimetric and spectrophotometric determination of some antimicrobial drugs in their pharmaceuticals. Spectrochim Acta Part A Mol Biomol Spectrosc. 2018;188:525-36.

6. Pritam S Jain, Vishal B Badgujar, Gayatri B Patil HPC and SJS. Estimation of Cefdinir in Bulk Drug Using Area Under Curve Method. Acta Sci Pharm Sci. 2018;2(1):7-10.

7. Al-ameri SAH. Application of DPP for the determination of cefdinir in pharmaceuticals. Glob J Sci Front Res B Chem. 2017;17(1):27-32.

8. Ojeda CB, Rojas FS. Separation and preconcentration by cloud point extraction procedures for determination of ions: recent trends and applications. Microchim Acta. 2012;177(1-2):1-21.

9. de Almeida Bezerra M, Zezzi Arruda MA, Costa Ferreira SL. Cloud point extraction as a procedure of separation and pre-concentration for metal determination using spectroanalytical techniques: A review. Appl Spectrosc Rev. 2005;40(4):269-99.
10. Hassan MJM, Al-hraishawi TJ. Batch and Cloud Point Extraction Spectrophotometric Methods for the Determination of Two Types Catecholamine Drugs. Int J ChemTech Res. 2017;10(9):756-68.

11. Mohammed J M, Hassan MS. Cloud Point Extraction Spectrophotometric Method for Determination of Three Types of Cephalosporin via Diazotization Reactions with Different Reagents. Brazilian J Anal Chem. 2017;4(17):24-36.

12. Gürkan R, Altunay N. Preconcentration and indirect quantification of trace nitrite, nitrate and total nitrite in selected beverage and milk samples using ionpairing cloud-point extraction with acridine orange. J Food Compos Anal. 2018;69:129-39.

13. Laespada MEF, Pavon JLP, Cordero BM. Micellemediated methodology for the preconcentration of uranium prior to its determination by flow injection. Analyst. 1993;118(2):209-12.

14. Fang Q, Yeung HW, Leung HW, Huie CW. Micellemediated extraction and preconcentration of ginsenosides from Chinese herbal medicine. J Chromatogr A. 2000;904:47-55.

15. Zhang $\mathrm{K}, \mathrm{Hu} \mathrm{Y}, \mathrm{Li}$ G. Diazotization-coupling reaction-based selective determination of nitrite in complex samples using shell-isolated nanoparticleenhanced Raman spectroscopy. Talanta. 2013;116:712-8.

16. Sudhir MS, Nadh RV. Diazo-Coupling: A Facile Mean for the Spectrophotometric Determination of Rasagiline Hemitartrate. Orient J Chem. 2014;29(4):1507-14.

17. Kenawy IMM, Khalifa ME, Hassanien MM, Elnagar MM. Application of mixed micelle-mediated extraction for selective separation and determination of $\mathrm{Ti}(\mathrm{IV})$ in geological and water samples. Microchem J [Internet]. 2016 Jan 1 [cited 2018 Jun 1];124:149-54. Available from: https://www.sciencedirect.com/science/article/pii/SO0 26265X15001757

18. 18. Hamrapurkar P, Patil P, Phale M, Gandhi M, Pawar S. A developed and validated stabilityindicating reverse-phase high performance liquid chromatographic method for determination of cefdinir in the presence of its degradation products as per International Conference on Harmonization guidelines. Pharm Methods [Internet]. 2011;2(1):1520 .

19. de Andrade JK, de Andrade CK, Felsner ML, Quináia $\mathrm{SP}$, dos Anjos VE. Pre-concentration and speciation of inorganic antimony in bottled water and natural water by cloud point extraction with Electrothermal Atomic Absorption Spectrometry. Microchem J. 2017;133:222-30.

20. Blanchet-Chouinard G, Larivière D. Determination of $\mathrm{Pb}$ in environmental samples after cloud point extraction using crown ether. Talanta [Internet]. 2018 Mar 1 [cited 2018 Jun 2];179:300-6. Available from: https://www.sciencedirect.com/science/article/pii/SO0 39914017311438

21. Gao N, Wu H, Chang Y, Guo X, Zhang L, Du L, et al. Mixed micelle cloud point-magnetic dispersive $\mu$ solid phase extraction of doxazosin and alfuzosin. Spectrochim Acta Part A Mol Biomol Spectrosc. 
2015;134:10-6.

22. Yao B, Yang L. Cloud point extraction of acetic acid from aqueous solution. Sep Sci Technol. 2009;44(2):476-90.

23. Qin H, Yu G, Chen M, Zou Y, Yang Y. Ultrasonicthermostatic-assisted cloud point extraction coupled to high-performance liquid chromatography for the analysis of adrenalines residues in milk. Eur Food Res Technol. 2012;234(3):543-50.

24. Pourreza N, Golmohammadi H. Colorimetric sensing of copper based on its suppressive effect on cloud point extraction of label free silver nanoparticles. Anal Methods [Internet]. 2014;6(7):2150-6.

25. Ghasemi E, Kaykhaii M. Application of Micro-cloud point extraction for spectrophotometric determination of Malachite green, Crystal violet and Rhodamine B in aqueous samples. Spectrochim Acta Part A Mol Biomol Spectrosc. 2016;164:93-7.

26. Reffas H, Benabdallah T, Youcef MH, Ilikti H. Study on the Cloud Point Extraction of Copper ( II ) from an Aqueous Sulfate Medium with N, N ' -Bis (salicylideneaminoethyl) amine Polydentate Schiff Base into a Nonionic Surfactant Phase. J Chem Eng Data. 2010;55(II):912-8.

27. El-Shahawi MS, Hamza A, Al-Sibaai AA, Bashammakh AS, Al-Saidi HM. A new method for analysis of sunset yellow in food samples based on cloud point extraction prior to spectrophotometric determination. J Ind Eng Chem [Internet]. 2013 Mar 25 [cited 2018 Jun 16];19(2):529-35.

28. Abdel-Aziz O, Farouk M, Nagi R, Abdel-Fattah L. Simple spectrophotometric and HPTLCdensitometric methods for determination of cefdinir in bulk powder and pharmaceuticals, and in presence of its hydrolytic degradation products. J Appl Pharm Sci. 2014;4(7):129-36.

29. Narala SR, Saraswathi K. Application of Oxidants to the Spectrophotome tric Determination of Cephalosporins (Cefditoren Pivoxil and Cefdinir) In Formulations. Tablet. 2011;1(200):187-99.

30. Gouda AA, Hashem H, Hassan W. Spectophotometric methods for determination of cefdinir in pharmaceutical formulations via derivatization with 1,2-naphthoquinone-4-sulfonate and 4-chloro-7-nitrobenzo-2-oxa-1, 3-diazole. Drug Test Anal. 2012;4(12):991-1000.

31. Singh BK, Parwate D V, Srivastava S, Shukla S. Selective and non-extractive spectrophotometric determination of cefdinir in formulations based on donor-acceptor complex formation. Quim Nova. 2010;33(7):1471-5.

\section{طريقة طيفية جديدة لتقدير السيفدينير بالاستخلاص بنقطة الغيمة

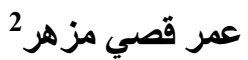

\author{
محمد جاسم محمد حسن 1

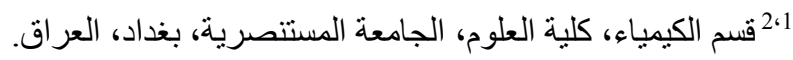

تم تطوير طريقة طيفية حساسة لتقدير عقار السيفدينير (CFD)، هذا البحث يتضمن على طريقتن. تتضمن الطريقة الأولى تحضير

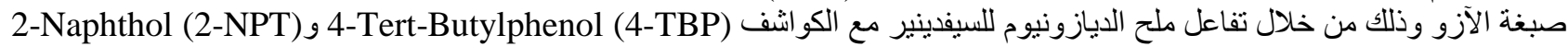

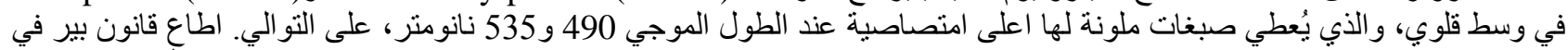

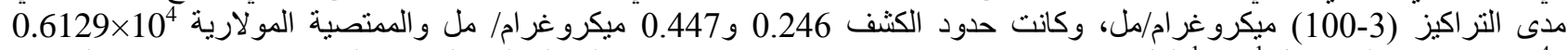

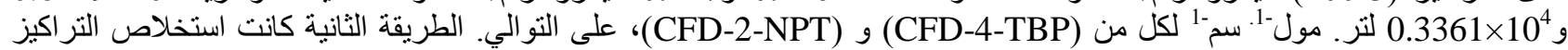

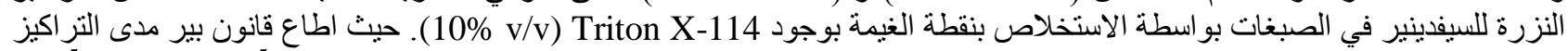

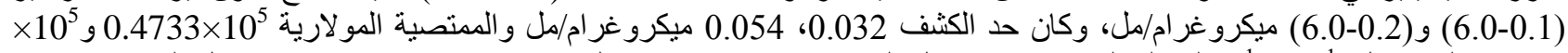

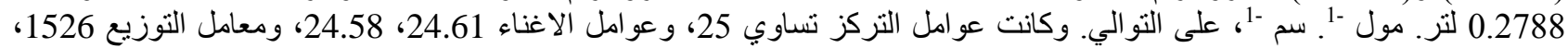

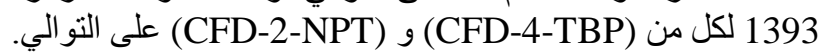

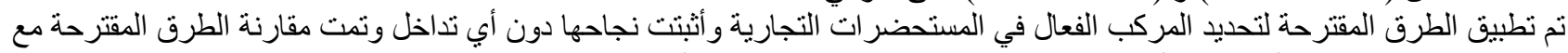
طريقة منشورة في تقدير السيفدينير النقي وتبين انه لا يوجد التتلاف و اضح بين الطرق. الكلمات المفتاحية: سيفدينير ، الأزوتة، نقطة الغيمة، طيفية، نرايتون اكس-114 